\title{
Are the Mental State Verbs Important for Roma Children's Understanding of False Belief Task
}

\author{
О важности глаголов, отражающих психические \\ состояния, при осознании цыганскими детьми \\ феномена ложных убеждений
}

\author{
Hristo Kyuchukov \\ Dr. in Pedagogy, \\ Professor
}

\author{
E-mail: hkyuchukov@gmail.com \\ https://orcid.org/0000-0002-1965-8908 \\ ResearcherID: E-5677-2015
}

\section{University of Silesia}

12, Bankowa Str., Katowice, Poland, 40-007
Селезский университет в Катовице

$\triangle$ ул. Банковая, 12, Катовице, Польша, 40-007

Original manuscript received September 04, 2019

Revised manuscript accepted March 25, 2020

\begin{abstract}
Objectives. The aim of the paper is to analyze the process of acquisition of mental state verbs in Romani and in Bulgarian langauges simultaneously by bilingual Roma children. The mental state verbs help the children to understand the Fals Belief Tasks, which predict the Theory of Mind. The theory of mind from other side is important for understanding the intentions, desires, jokes, motivations of others and what are the factors influencing the development of theory of mind

Research methods and techniques. Two Roma children from Bulgaria (1 boy and 1 girl) aged 1,0-3,0 years were audiorecorded longitudinally in their natural home environment. According to M. Taumoepeau and T. Ruffman (2006), the mental state verbs can be grouped in different categories, showing different states: mental states, physical states, emotions, perception and cognition. The acquired verbs are analyzed qualitatively and quantitatively.
\end{abstract}


Results. The data shows that some mental state verbs are acquired in Romani and others in Bulgarian. The factors influencing the acquisition of part of the verbs in Romani and the other part in Bulgarian are analyzed. Mental state verbs are important for the cognitive development of the children. The results show that the the boy uses 100\% Romani mental state verbs: very high number of verbs are related to (1) mental states, e.g.: mangav (want), dehav (love), arakhav (care about), džanav (know); (2) emotions: xavxoli (angry), khanile (feeling bad); (3) physical state, e.g.: dukhal (hurt), rovav (cry); (4) sense, such as: dikh (look). The girl uses $89.0 \%$ mental state verbs in Romani and $19.0 \%$ in Bulgarian language. The learned verbs by her are related to mental state from Romani: mangav (want), džanav (know), darav (be afraid) and from Bulgarian: obicham (love), znam (know), iskam (want). The other verbs from the field of emotions, physical state and sense are from Romani.

Conclusions. The resreach although limited has shown that sentences with mental state verbs in a combination with a noun phrase in a simple sentence are acquired around the age of 1,6. The more complex sentences with mental state verb and complementizer phrase are acquired around the age of 2,6 years old.

Key words: Roma, bilingualism, mental state verbs, theory of mind.

\section{Introduction}

After the use of the term Theory of Mind by D. Premack and G. Woodruf (1978) the developmental psychologists started to investigate what the children know about the minds of others. Most of the studies focused on the age of the children when they start to understand the intentions, desires, jokes, motivations of others and what are the factors influencing the development of theory of mind. For this purposes psychologist such as H. Wimmer and J. Perner (1983), and later the J. Perner et al. (1987), A. Gopnic and J. Astington (1988) developed the two classical False Belief Tasks in psychology known as «Maxi task» and «Smarties task» which are predicting the development of the Theory of Mind in children.

In 1990-s psychologist interested in language development such as Villiers de and Pyers J. (1997), Astington J. and Jenkins J. (1999) started to investigate the relationship between the development of the language and the understanding of False Belief Tasks. Villiers (2007) was interested in syntax and particularly in wh-questions used with mental state verbs and trying to prove that the early knowledge of the children of verbs such as «know», «think», «say» are important for the 
correct answer of the theory of mind questions in False Belief Tasks. Astington J. and Jenkins J. (1999) also found that a strong relationship between the language abilities of children and theory of mind tasks. If a child does not understand the meaning of words showing «mental states» such as «think», «know», «remember», most probably s/he will not answer correctly to the questions in False Belief Task. According to the authors the language development helps the development of theory of mind.

The mental state verbs are verbs which show different mental conditions and mental states of a person. According to Perner et al. (2002), the mental state verbs are predictors of the early understanding of the theory of mind. Theory of mind is the ability of the children to understand the desires, intentions and wishes of others.

Taumoepeau M., and Ruffman T. (2006), in a study with mothers of 15 to 24-month-old infants, assessed the relation between the mother's mental state language and the child's language of desire and emotion understanding. The mothers described pictures to their infants and mother talk was coded for mental and non-mental state language. Children were administered two emotion understanding tasks and their mental and non-mental state vocabulary levels were obtained via parental report. The results demonstrated that the mother's use of desire language with 15-month-old children uniquely predicted a child's later mental state language and emotional task performance, even after accounting for potentially confounding variables. In addition, the mother's tendency to refer to the child's desires over desires of others was the more consistent correlate of mental state language and emotion understanding. They classified the verbs used in six categories. Verbs showing the following:

1. Mental state - want, hope, wish, care about, afraid that, like, love, dream, prefer, keen on; think, know, belief, expect, wonder;

2. Physical state - cry, smile, laugh, giggle, hurt, in pain, ill;

3. Emotion - annoyed, hurtful, bored, unhappy, feel bad, sad, upset, feed up, miserable, cross, grumpy, angry, mad, scared, shy, surprised, pleased, happy, enjoy, excited, fun, interested, frustrated, missed, disgusted, ok [feel ok], good [feel good], better; 
4. The senses - look, listen, cold [the body feeling cold], hot [the body feeling hot];

5. Cognitive - hard [difficult], remember, guess, dream, forget, mean [I mean that]. real;

6. Modulations of assertion - might, bet, curious, expect, sure, definitely, possibly, may be, wonder, suppose, certain, certainly, could be, perhaps, reckon, figure, guess, must, probably.

In one of the earlier studies by Shatz M., Wellman H., and Silber Sh. (1983) on mental state verbs, the authors analysed in naturally occurring speech the young child's ability to contemplate and communicate about his/her mental state. In the first study, the authors showed the frequency and function of verbs of mental reference such as think and know in the speech of one child from age 2,4 to 4,0. In the second study, they examined shorter samples of speech collected from 30 two-year-olds over a six-month period. The results from both studies suggest that the earliest uses of mental verbs are for conversational functions rather than for mental reference. The authors concluded that the first attempts at mental reference begin to appear in some children's speech in the second half of the third year of age. Since most of the children studied exhibited the linguistic knowledge necessary to make reference to mental states, the authors concluded that the absence of such reference earlier suggests that children still younger lack an awareness of such states, or at the very least, an understanding of their appropriateness as topics of conversation.

The relationship between mental state verbs and sentential complements (S-comps) was investigated by Nixon S. (2005) in language samples of 40 four-year-old children. Mental state verbs are coded by the author by function (cognitive, sensory, or pragmatic), complement (simple, simple+, or S-comp) and expression of certainty. Children produce a total of 14 , but only five different mental state verbs. Approximately equal numbers of mental state verbs had cognitive and pragmatic functions. The mental state verbs referring to cognitive states were more likely to occur with sentential compliments than mental state verbs used as pragmatic markers. Sentential compliments were more likely to occur with uncertain rather than certain mental state verbs. Utterances containing mental state verbs were longer than utterances with other matrix verbs, but mental state verbs and sentential compliments were strongly correlated after adjusting for utterance 
length. The sentential compliments occurred more often with mental state verbs than with other matrix verbs.

In another study, Howard A., Mayeux L., and Naigles L. (2008) examined how the mothers use mental verbs in conversations with three- and four-year-old children and link these usages to the children's developing understanding of mental verbs and a theory of mind. Sixty three- and four-year-olds, either attending or non-attending pre-school, were given tasks assessing mental verb distinctions and false belief. Their mothers' mental verb use was coded for frequency, type of utterance, type of subordinate clause, the person of the subject of the verb, and the certainty of the verb think. Among the three-year-olds, the children who did not attend pre-school performed significantly better on the mental verb comprehension task. Comparing the mothers whose children attended pre-school with mothers whose children did not, the mothers of children not attending pre-school were found to use fewer less statements and more questions, fewer first person utterances and more second-person utterances, and the verb think in its 'very certain' form was used less often. In regression analyses, the authors found that the children's mental verb and false belief performance were positively predicted by maternal mental verb questions, and single clause utterances. These findings indicated how maternal input has the potential to promote or hinder children's understanding of the mind.

Booth J., Hall W., Robison G., and Kim S. (1997) found out that the children's use of the mental state verb know was correlated positively with the number of different cognitive words which are related to semantic processes, and the parental use of those same cognitive words. This suggests that parental linguistic input may be an important mechanism in cognitive word acquisition. Young children tended to use know more to refer to themselves than to refer to others, whereas their parents tended to use know equally to refer to self and others. The importance of cognitive words in a theory of language acquisition is discussed in this study.

The studies mentioned here show the importance of input by mothers/adults and their use of verbs showing different mental sates. All the studies were done with English-speaking children and mothers and all the findings are typical for English-speaking societies. These studies show the importance of the language for development of the theory of mind in young children. However, as Villiers (2007) notes, more 
experimental linguistic work is needed with other populations. This could result in new knowledge and allow for a more precise delineation of how language and theory of mind interrelate at the interface.

The previous research has shown that children using mental state verbs in early childhood reach and comprehend aspects of the theory of mind earlier, around the age of four. The more developed the child's mentalistic vocabulary is, the more successful they are in performing theory of mind tests (Astington, 1998; Ruffman, 2014).

From the previous studies it is known that the verbs for desire and emotions are acquired before the verbs for cognitive state; the verbs for perception and the verbs for physical state precede the verbs for mental state (de Villiers, 2007). Here are some examples of the syntax order with different mental state verbs.

The use of the verb want. The syntax of the early mental state verbs is simpler:

1. V+NP: John wants an apple.

2. $V+C P$ (complementizer phrase): John wants to buy an apple.

3. $V+C P$ (with explicit subject): John wants Bill to buy an apple.

The use of the verb think:

4. V+PP: John thinks about an apple.

5. V+CP: John thinks that he will buy an apple.

6. V+CP: John thinks that Sally bought an apple (but she did not).

The use of the verb remember:

7. $V+N P$ : John remembers his bag.

8. $V+C P$ : John remembers to pick up his bag.

9. $V+C P$ : John remembers that he left his bag.

\section{The Study}

In this study, I seek to observe the spontaneous use of mental state verbs by parents and by children. Two Roma children (one boy A. and one girl - B. speakers of Romani dialect of Sofia, Bulgaria were longitudinally audio recorded (between the ages of 1,0-3,0) in their natural home environment. The children were recorded twice a month by a trained Roma woman, a member of the community. All recordings were transcribed and analysed. 
Are the Mental State Verbs Important For Roma Children's...

I attempt to answer the following research questions:

- Is the emergence of the mental state verb the same in a very different language and cultural context such as Romani?

- Are the mental state verbs richer in Romani than in Bulgarian as a L2?

- Could this explain the discrepancy in acquiring the theory of mind in L1 vs. L2?

The working hypotheses are the following:

- H1: Roma children growing up bilingually will naturally learn the mental state verbs in their L2 as well.

- H2: The use of mental state verbs from a very early age helps the bilingual children to understand the theory of mind earlier in their L2.

\section{Results}

In our previous study with Roma children between 3,0-4,6 years old we found that the theory of mind scores in Romani as L1 are higher than the scores in Bulgarian as L2. With increase of age, the knowledge of the children improves (Kyuchukov, 2010).

In this study I attempt to analyze the data of both children. They were recorded in their natural home environment during everyday activities. Comparing the production of the children, one can see that the boy A. is more talkative then the girl B. He has a higher number of produced utterances. This is shown in Table 1.

Table 1. Total number of utterances

\begin{tabular}{cc}
\hline Child & Number of utterances \\
\hline Boy $A$ & 2088 \\
Girl B & 1313 \\
\hline
\end{tabular}

We can observe how the children use the mental state verbs and whether they also have verbs in Bulgarian or only in Romani as their mother tongue. This is shown in Table 2.

As one can see from Table 2, the boy A is growing up monolingually and he uses only Romani mental state verbs. The girl $\mathrm{B}$, by contrast, is growing up bilingually and she has acquired 15 
mental state verbs in Bulgarian as well. The parents of the girl B speak Bulgarian at home more often and she easily picks up some Bulgarian vocabulary as well as her L2.

Table 2. The use of mental state verbs

\begin{tabular}{ccc}
\hline Child & Romani (L1) & Bulgarian (L2) \\
\hline Boy $A$ & 178 & - \\
Girl B & 66 & 15 \\
\hline
\end{tabular}

However, if we compare the acquired mental state verbs one can see that the boy A has $8.4 \%$ and the girl B has $6.1 \%$ mental state verbs as based on the total number of the utterances. Although both children are the same age, the boy $\mathrm{A}$ is more talkative and has a higher number of utterances, respectively a higher percent of acquired mental state verbs than the girl $\mathrm{B}$. Comparing the mental state verbs produced in Romani as L1 and in Bulgarian as L2 by the boy A and the girl $\mathrm{B}$, one can see that the boy A uses only Romani mental state verbs $(100 \%)$ and the girl B has $81 \%$ of verbs uttered in Romani (L1) and $19.0 \%$ of verbs uttered in Bulgarian. She has learned some mental state verbs in Bulgarian. It is interesting to see which mental state verbs are first learned. Table 3 displays the verbs acquired by the boy A. The table shows that Kocho has a very high number of verbs related to (1) mental states, e.g.: mangav (want), dehav (love), arakhav (care about), džanav (know); (2) emotions: xavxoli (angry), khanile (feeling bad); (3) physical state, e.g.: dukhal (hurt), rovav (cry); (4) sense, such as: dikh (look).

Table 3. Mental state verbs used by the boy A

\begin{tabular}{llll}
\hline Mental state & Emotions & Physical state & Sense \\
\hline Mangav (want) 65 & xavxoli (angry) 13 & dukhal (hurt) 20 & Dikh (look) 65 \\
Dehav (love) 16 & Khanile (feel bad) 12 & rovav (cry) 11 & - \\
Arakhav (care about) 11 & - & - & - \\
Džanav (know) 11 & - & - & - \\
\hline
\end{tabular}

The mental state verbs used by the girl B are more diverse. The child has grown up with both languages, Romani and Bulgarian, and she has learned some Bulgarian mental state verbs together with the Romani ones. In the case of the girl B, the highest learned verbs are also those 
showing mental state from Romani: mangav (want), džanav (know), darav (be afraid) and from Bulgarian: obicham (love), znam (know), iskam (want). The other verbs from the field of emotions, physical state and sense are from Romani. This can be seen in Table 4.

Table 4. Mental state verbs used by the girl B

\begin{tabular}{llll}
\hline Mental state & Emotions & Physical state & Sense \\
\hline Mangav (want) 20 & denilo (mad) 4 & rovav (cry) 5 & dikh (look) 14 \\
Džanav (know) 11 & - & - & - \\
Darav (be afraid) 12 & - & - & - \\
Obicham (love) 4 & - & - & - \\
Znam (know) 3 & - & - & - \\
Iskam (want) 8 & - & - & - \\
\hline
\end{tabular}

Here are some examples of mental state verbs first used:

1. Adult: Celodijes naxas, štom avav me togavaxas. whole day no eat, when come-1sg. I than eat-2sg.

You do not eat the whole day and when I come then you start to eat. Boy A $(\mathbf{1 , 5 )} \check{C} u k a$ mangav!

like that want-1sg.

I want it like that.

2. Adult Ajde opa pištine e Aliske.

get up call-3sg the Ali-to

Get up and call Ali.

Girl B $(\mathbf{1 , 4 )}$ Na mangav

not want-1sg.

I do not want.

The Romani language is rich in mental state verbs. Being an oral language and using a different folklore genre drawn from Romani culture and folklore, making use of jokes and teasing in the communication process with the children, from a very early age they hear diverse types of mental state verbs. Most of them are used in the folklore genre of songs and fairytales, such as love, hate, afraid, want, know, etc.

\section{Conclusion and Discussion}

Mental state verbs in a combination with a noun phrase in a simple sentence are acquired around the age of 1,6. Structures such as: 
1. V+NP: Mangav shokoladi.

I want chocolate.

Can be easily learned even when the child does not have enough lexical knowledge.

Structures such as:

2. V+CP: Mangav te dikhav avri

I want to look outside.

Are acquired around the age of 2,6. It seems that the structures such as $\mathrm{V}+\mathrm{CP}$ (with an explicit subject) in Romani are acquired much later.

It would appear clear that in different cultures the mental state verbs play a different role in the cognitive development of the children. In Romani, due to the cultural special features in the upbringing of children, the children have access to a rich variety of mental state verbs from very early age.

The data is limited, and it cannot be stated that the mental state verbs in Romani are richer than in Bulgarian. To our knowledge, to date there has been no research on the acquisition of mental state verbs in Bulgarian and thus we cannot generalize. But what can be said is that the Roma children learn the mental state verbs in Romani first and some Bulgarian mental state verbs are also acquired, because the children grow up in families where the parents also speak Bulgarian at home.

Kyuchukov H. (2010) has shown that the children are better performing the theory of mind tasks in their mother tongue than in Bulgarian, the lack of sufficient knowledge of mental state verbs in Bulgarian could be one of the reasons for the poorer level of performance of the theory of mind tasks in Bulgarian.

The data of the girl B showed that Roma children growing up bilingually will learn naturally the mental state verbs in their L2 as well. This was the first hypothesis. The rich and diverse use of the mental state verbs in their L2 from a very early age can help them understand the theory of mind earlier in their L2.

Unfortunately, in contemporary Europe the knowledge of the Romani language among Roma children is not valued as an asset. In many countries, the children are still being placed in special schools based on psychological tests administered in the official language of the country where the children live. If the Roma children cannot perform the tests correctly, they are classified as 'mentally retarded' and placed in special schools. The contemporary school system in Europe does not 
have a tool to measure the Roma children's knowledge pertaining to complex grammatical categories that are shown in this article and are acquired in the family from a very early age.

\section{References}

Astington, J.W. (1998). Theory of Mind Goes to School. Educational Leadership, 56 (3), 46-48.

Astington, J.W., \& Jenkins, J.M. (1999). A Longitudinal Study of hhe Relation Between Language and Theory-of-Mind Development. Developmental Psychology, 35, 1311-1320. https://doi.org/10.1037/0012-1649.35.5.1311

Booth, J., Hall, W., Robison, G., \& Kim, S. (1997). Acquisition of the Mental State Verb Know by 2- to 5-year-old Children. Journal of Psycholinguistic Research, 26 (6), 581-603. https://doi.org/10.1023/A:1025093906884

Gopnik, A., \& Astington, J. (1988). Children's Understanding of Representational Change and Its Relation to the Understanding of False Belief and the Appearance-Reality Distinction. Child Development, 59 (1), 26-37. https://doi. org/10.2307/1130386

Howard, A., Mayeux, L., \& Naigles, L. (2008). Conversational Correlates of Children's Acquisition of Mental Verbs and a Theory of Mind. First Language, 28 (4), 375-402. https://doi.org/10.1177/0142723708091044

Kyuchukov, H. (2010). Cognitive Development and Theory of Mind in Bilingual Children. In B. Bokus (Ed.), Studies in the Psychology of Language and Communication (pp. 211-225). Warsaw: Matrix.

Nixon, S. (2005). Mental State Verb Production and Sentential Complements in Four-Year-Old Children. First Language, 21 (1), 19-37. https://doi. org/10.1177/0142723705046898

Perner, J. et al. (1987). Three-Year Olds' Difficulty With False Belief: The Case for a Conceptual Deficit. British Journal of Developmental Psychology, 5, 125-137. https://doi.org/10.1111/j.2044-835X.1987.tb01048.x

Perner, J. et al. (2002). Theory of Mind Finds Piagetian Perspective: Why Alternative Naming Comes With Understanding Belief. Cognitive Development, 17, 14511472. https://doi.org/10.1016/S0885-2014(02)00127-2

Premack, D., \& Woodruff, G. (1978). Does the Chimpanzee Have a Theory of Mind? Behavioral and Brain Sciences, 1 (4), 515-526. https://doi.org/10.1017/ S0140525X00076512

Ruffman, T. (2014). To Belief or Not Belief: Children's Theory of Mind. Developmental Review, 34 (3), 265-293. https://doi.org/10.1016/j.dr.2014.04.001

Shatz, M., Wellman, H., \& Silber, Sh. (1983). The Acquisition of Mental Verbs: A Systematic Investigation of the First Reference to Mental State. Cognition, 14, 301-321. https://doi.org/10.1016/0010-0277(83)90008-2

Taumoepeau, M., \& Ruffman, T. (2006). Mother and infant talk about mental states relates to desire language and emotion understanding. Child Development, 77 (2), 465-481. https://doi.org/10.1111/j.1467-8624.2006.00882.x

Villiers de, J. (2007). The interface of language and Theory of Mind. Lingua, 117 (11), 1858-1878. https://doi.org/10.1016/j.lingua.2006.11.006 
Villiers de, J.G., \& Pyers, J. (1997). Complementing cognition: the relationship between language and theory of mind. In Proceedings of the $21^{\text {st }}$ annual Boston University Conference on Language Development. Somerville, MA: Cascadilla Press.

Wimmer, H., \& Perner, J. (1983). Beliefs about beliefs: representation and constraining function of wrong beliefs in young children's understanding of deception. Cognition, 13, 103-128. https://doi.org/10.1016/0010-0277(83)90004-5

\begin{abstract}
АННОТАЦИЯ
Цель статьи - проанализировать процесс приобретения цыганскими детьмибилингвами глаголов, отражающих психические состояния, на ромском и болгарском языках. Релевантные психическим состояниям глаголы помогают детям понять феноменологию ложных убеждений, которая постулируется в рамках концепции Теории Разума. Указанная концептуализация с другой стороны является важным средством для исследовательского понимания намерений, желаний, шуток, мотиваций других людей и определения факторов, влияющих на развитие сознания.
\end{abstract}

Процедура исследования. В экспериментальную выборку лонгитюдного исследования вошли двое цыганских детей из Болгарии (1 мальчик и 1 девочка) в возрасте 1,0-3,0 лет, речевая активность которых фиксировалась с помощью аудиозаписи в их естественной домашней среде. По мнению M. Taumoepeau u T. Ruffman (2006), глаголы, отражающие психические состояния, можно группировать по различным категориям, связанным с различными состояниями: психическими, физическими, эмоциями, восприятием и познанием. Приобретенные глаголы анализировались по качественным и количественным критериям.

Результаты. Полученные данные показывают, что определенные глаголы, отражающие психические состояния, приобретаются детьми с ромского языка, а другие - с болгарского. Проанализированы факторы, влияющие на приобретение определенной части ромских и болгарских глаголов, соответственно. Установлено, что глаголы, отражающие психические состояния, важны для развития познавательных функций детей. Результаты показали, что исследуемый мальчик использовал в общении все $100 \%$ глаголов цыганского языка, отражающие психические состояния: в частности, подавляющее большинство глаголов связана с (1) психическими состояниями, например: мангав (хочу), дехав (любовь), арахав (заботиться о), джанав (знать); (2) эмоциями: ксавксоли (сердитый), Ханиль (плохо себя чувствовать); (3) физическими состояниями, например: духал (больно), ровав (плакать); (4) восприятием, такой глагол как: дих (смотреть). Исследуемая девочка использовала 89,0\% глаголов, отражающие психические состояния, с цыганской языка и 19,0\% слов - с болгарского. Усвоенные ею глаголы, связанные с психическими состояниями, с цыганского языка: мангав (хочу), джанав (знать), дарав (бояться) и с болгарского: сбоку (любовь), знам (знаю), искам (хочу). 
Are the Mental State Verbs Important For Roma Children's...

Другие глаголы из среры эмочий, физического состояния и восприятия относятся к цыганской речи.

Выводы. Несмотря на ограничения, исследование показало, что предложения с глаголами, которые отражают психические состояния, в сочетании с именительным словосочетанием в простом предложении, появляются примерно в возрасте 1,6 лет. Более сложные предложения с глаголами, отражающие психические состояния, и содержащие дополняющие или завершающее словосочетания, появляются в возрасте 2,6 лет.

Ключевые слова: Рома, двуязычие, глаголы, психические состояния, теория разума.

Кючуков Христо. Щодо важливості дієслів, що відображають психічні стани, при усвідомленні ромськими дітьми феномену помилкових переконань

\begin{abstract}
АНОТАЦІЯ
Мета статmі - проаналізувати процес набуття ромськими дітьми-білінгвами дієслів, що відображають психічні стани, в ромській та болгарській мовах. Релевантні психічним станам дієслова допомагають дітям зрозуміти феноменологію помилкових переконань, яка постулюється в рамках концепції Теорії Розуму. Зазначена концептуалізація з іншого боку є важливим засобом для дослідницького розуміння намірів, бажань, жартів, мотивацій інших людей та визначення факторів, що впливають на розвиток свідомості.

Процедура дослідження. До експериментальної вибірки лонгитюдного вивчення увійшло двоє ромських дітей з Болгарії (1 хлопчик та 1 дівчинка) у віці 1,0-3,0 років, мовна активність яких фіксувалась за допомогою аудіозапису в їхньому природному домашньому середовищі. На думку М. Taитоереаи $i$ T. Ruffman (2006), дієслова, що відображають психічні стани, можна групувати в різні категорії, пов'язані з різними станами: психічними, фізичними, емоціями, сприйняттям та пізнанням. Набуті дієслова аналізувалися за якісним та кількісним критеріями.
\end{abstract}

Результати. Отримані дані демонструють, що певні дієслова, які відображають психічні стани, набуваються дітьми з романської мов, а інші з болгарської. Проаналізовано фактори, що впливають на набуття частини романських та болгарських дієслів, відповідно. Встановлено, що дієслова, які відображають психічні стани, є важливими для розвитку пізнавальних функцій дітей. Результати показали, що досліджуваний хлопчик використовував у спілкуванні всі 100\% ромських дієслів, що відображають психічні стани: зокрема, переважна кількість дієслів пов'язана з (1) психічними станами, наприклад: мангав (хочу), дехав (любов), арахав (дбати про), джанав (знати ); (2) емоціями: ксавксолі (сердитий), ханілє (погано себе почувати); (3) фізичними станами, наприклад: духал (боляче), ровав (плакати); (4) сприйняттям, таке дієслово як: діх (дивитися). Досліджувана дівчинка використовувала 89,0\% дієслів, що відображають психічні стани, з ромської мови та 19,0\% слів - з болгарської. 
О важности глаголов, отражающих психические состояния...

Засвоєнні нею дієслова, пов'язані з психічними станами, з ромської мови: мангав (хочу), джанав (знати), дарав (боятися) та з болгарської: обічам (любов), знам (знаю), іскам (хочу). Інші дієслова зі сфери емочій, фрізичного стану та сприйняття відносяться до ромської мови.

Висновки. Незважаючи на обмеження, дослідження продемонструвало, що речення з дієсловами, які відображають психічні стани, в поєднанні з іменниковим словосполученням у простому реченні, з'являються приблизно у віці 1,6 років. Більш складні речення з дієсловами, що відображають психічні стани, та містять доповнювальне або завершальне словосполучення, з'являються у віці 2,6 років.

Ключові слова: Рома, двомовність, дієслова, психічні стани, теорія розуму. 